\title{
AQBD ASSISTED SPECTROPHOTOMETRIC METHODS FOR THE QUANTIFICATION OF CEFIXIME TRIHYDRATE USING TWO OXIDATIVE COUPLING AGENTS
}

\author{
KOKILAMBIGAI K S, LAKSHMI K S* \\ Department of Pharmaceutical Analysis, SRM College of Pharmacy, SRM Institute of Science and Technology, Kancheepuram, Tamil Nadu, \\ India. Email: kskai83@gmail.com
}

Received: 21 April 2019, Revised and Accepted: 28 May 2019

ABSTRACT

Objective: The present study focuses on developing two visible spectrophotometric methods for cefixime trihydrate (CFT) by the utilization of analytical quality by design space concept. The critical method variables were screened and optimized by factorial design.

Methods: In methods A and B, CFT reacts with 3-methyl-2-benzothiazolinone hydrazone hydrochloride in an acidic medium having $\lambda_{\text {max }}$ at 630 nm and CFT reacts with 1, 10 phenanthroline (Phen) showing $\lambda_{\max }$ at $510 \mathrm{~nm}$, respectively. Fractional factorial design was employed for the initial screening of independent variables for both methods. The main, interaction, and quadratic effects of the most significant factors on the preferred response (absorbance) for methods A and B were studied employing central composite design (CCD) with response surface methodology.

Results: The method was linear ( $\mathrm{r}^{2}=0.9983$ and 0.9986 for methods $\mathrm{A}$ and $\mathrm{B}$ ), accurate (mean recovery $=100.06 \%$ and $99.26 \%$ for methods $\mathrm{A}$ and $\mathrm{B}$ ), precise (relative standard deviation, \% relative standard deviation $=0.9214,1.025$ and $0.1919,0.2136$ for methods $\mathrm{A}$ and $\mathrm{B}$ ).

Conclusion: The outcome of the proposed work has evidently revealed that quality by design concept can be efficiently enforced in the optimization of spectrophotometric technique for the quantification of CFT in pharmaceutical raw materials and formulations by minimum experimental runs.

Keywords: Cefixime trihydrate, Quality by design, Fractional factorial design, Response surface methodology, Central composite design, Visible spectrophotometry, Validation.

(C) 2019 The Authors. Published by Innovare Academic Sciences Pvt Ltd. This is an open access article under the CC BY license (http://creativecommons. org/licenses/by/4. 0/) DOI: http://dx.doi.org/10.22159/ajpcr.2019.v12i7.33682

\section{INTRODUCTION}

Cefixime trihydrate (CFT) chemically, [(6R, 7R)-7-[2-(2-amino-4thiazolyl)glyoxylamido]-8-oxo-3-vinyl-5-thia-1-azabicyclo[4.2.0]oct2-ene-2-carboxylic acid, $7^{2}$-(Z)-[0-(carboxy methyl)oxime] trihydrate] (Fig. 1), a third-generation cephalosporin is an oral broad-spectrum antibiotic that is highly active against various bacterial strains such as Enterobacteriaceae, Haemophilus influenzae, and Streptococcus pyogenes [1].

A detailed study on the analytical methods employed for the estimation of CFT includes spectrophotometry [2-12], spectrofluorimetry [7], voltammetry [13], and high-performance liquid chromatography (HPLC) $[2,4,14,15]$ as a single component. The analysis of multicomponent formulations of CFT includes spectrophotometric methods [16-18], HPLC [19-21], and highperformance thin-layer chromatography, HPTLC [22-24] methods. The reported spectrophotometric methods [11,12] utilize one variable at a time, and hence, the method is ineffective and yields deceitful results, which are to be avoided [25]. This necessitates the use of a systematic and mathematical means of optimizing the reaction parameters to acquire crucial and precise results with less number of experiments. The experimental design is one of the most common effective chemometric optimization methods used to assess the impact of various conditions on the response by screening and optimizing the effects of selected factors [26]. Response surface methodology (RSM) is one of the mathematical and statistical tools in design space employed for the progress and optimization of the complex processes [27-29]. RSM is employed following the initial screening of the experimental variables that appreciably influence the response by means of factorial designs [27]. Central composite design, a response surface technique requires a minimum number of experiments and is utilized in the current study to optimize, validate, and analyze CFT spectrophotometrically. The experimental variables of the reported spectrophotometric methods $[11,12]$ were employed to optimize various reaction variables. Hence, our main aim of the work is to develop two visible spectrophotometric methods for CFT by the utilization of analytical quality by design space concept. The proposed method involves screening and optimization of the experimental variables by the concept of fractional factorial design (FFD), central composite design by RSM to develop visible spectrophotometric methods for estimating the content of CFT in pharmaceutical raw materials and formulations. The developed method was validated as per the ICH Q2 (R1) guidelines [30].

\section{EXPERIMENTAL}

Chemicals and solvents

- Distilled water

- Sodium hydroxide

- Hydrochloric acid

- Ferric chloride

- 3-methyl-2-benzothiazolinone hydrazone hydrochloride (MBTH) reagent

- 1,10 phenanthroline

- The reference standard of CFT was provided ex-gratia from orchid chemicals and Pharmaceuticals Ltd., Chennai, Tamil Nadu, India. Taxim-o $200 \mathrm{mg}$ (tablets) was procured from the local pharmacy.

\section{Instrumentation}

- PerkinElmer ultraviolet-visible spectrophotometer lambda 25

- Sonicator

- Electronic balance. 
Reagents and standards

Method A

A solution of MBTH $(0.2 \% \mathrm{w} / \mathrm{v}, 0.3 \% \mathrm{w} / \mathrm{v}$, and $0.4 \% \mathrm{w} / \mathrm{v})$ in $0.1 \mathrm{M} \mathrm{HCl}$ and $0.4 \% \mathrm{w} / \mathrm{v}, 0.5 \% \mathrm{w} / \mathrm{v}$, and $0.6 \% \mathrm{w} / \mathrm{v}$ solution of ferric chloride were prepared in $0.1 \mathrm{M} \mathrm{HCl}$.

\section{Method B}

A $0.1 \% \mathrm{w} / \mathrm{v}, 0.2 \% \mathrm{w} / \mathrm{v}$, and $0.3 \% \mathrm{w} / \mathrm{v}$ solutions of 1,10 phenanthroline reagent were prepared in ethanol. $0.4 \% \mathrm{w} / \mathrm{v}, 0.5 \% \mathrm{w} / \mathrm{v}$, and $0.6 \% \mathrm{w} / \mathrm{v}$ solutions of ferric chloride were prepared in distilled water.

\section{Method development}

Primary stock solution

Based on the preliminary solubility studies with various solvents, the drug was found to be freely soluble in sodium hydroxide. Hence, sodium hydroxide $(0.1 \mathrm{M})$ solution was used for preparing the primary stock solution of CFT $(1000 \mu \mathrm{g} / \mathrm{ml})$. Further dilutions were made with distilled water.

\section{Sample solution}

To determine the content of CFT in commercial tablets, 20 tablets weighed accurately and powdered. A portion of the tablet powder corresponding to $10.0 \mathrm{mg}$ of CFT was accurately weighed and transferred to $10.0 \mathrm{ml}$ volumetric flask. To this, $5 \mathrm{ml}$ of $0.1 \mathrm{M} \mathrm{NaOH}$ was added and sonicated for about $20 \mathrm{~min}$. The final volume was made up to mark with $0.1 \mathrm{M} \mathrm{NaOH}$, mixed well and filtered through membrane $(0.45 \mu)$ filter

\section{Two-level fractional factorial model}

Method A

A five-factor sixteen-run FFD was utilized to study the impact of the five independent variables, namely $\mathrm{MBTH}$ concentration $\left(\mathrm{X}_{1}\right)$, ferric chloride concentration $\left(\mathrm{X}_{2}\right)$, volume of MBTH reagent $\left(\mathrm{X}_{3}\right)$, volume of ferric chloride $\left(\mathrm{X}_{4}\right)$, and the reaction time $(\mathrm{RT})\left(\mathrm{X}_{5}\right)$, on the development of cefixime MBTH complex (absorbance). Based on the primary experiments conducted, the values incorporated in the model were in the following low and high levels: MBTH reagent concentration $\left(\mathrm{X}_{1}\right)$ : $0.2 \% \mathrm{w} / \mathrm{v}-0.4 \% \mathrm{w} / \mathrm{v}$; ferric chloride concentration $\left(\mathrm{X}_{2}\right): 0.4 \% \mathrm{w} / \mathrm{v}-$ $0.6 \% \mathrm{w} / \mathrm{v}$; volume of MBTH reagent $\left(\mathrm{X}_{3}\right): 1.5 \mathrm{ml}-2.5 \mathrm{ml}$ : Volume of ferric chloride $\left(\mathrm{X}_{4}\right): 1.5 \mathrm{ml}-2.5 \mathrm{ml}$; and the reaction time $\left(\mathrm{X}_{5}\right): 20-40 \mathrm{~min}$. The design matrix and their experimental runs are presented in Table 1.

\section{Method B}

A four-factor eight-run fractional factorial model was used to contemplate the impact of the four independent factors, namely 1,10 phenanthroline concentration $\left(\mathrm{X}_{1}\right)$, ferric chloride concentration $\left(\mathrm{X}_{2}\right)$, the heating time $\left(\mathrm{X}_{3}\right)$, and heating temperature $(\mathrm{HT})$ $\left(\mathrm{X}_{4}\right)$ on the development of cefixime - 1, 10 phenanthroline complex (absorbance). Based on the primary experiments conducted, the values used in the model were in the following ranges: 1,10 phenanthroline reagent concentration $\left(\mathrm{X}_{1}\right): 0.1 \% \mathrm{w} / \mathrm{v}-0.3 \% \mathrm{w} / \mathrm{v}$; ferric chloride concentration $\left(\mathrm{X}_{2}\right): 0.3 \% \mathrm{w} / \mathrm{v}-0.5 \% \% \mathrm{w} / \mathrm{v}$; the heating time $\left(\mathrm{X}_{3}\right): 15$ $-25 \mathrm{~min}$ and heating temperature $\left(\mathrm{X}_{4}\right): 35^{\circ} \mathrm{C}-40^{\circ} \mathrm{C}$. The design matrix and their experimental runs are presented in Table 2.

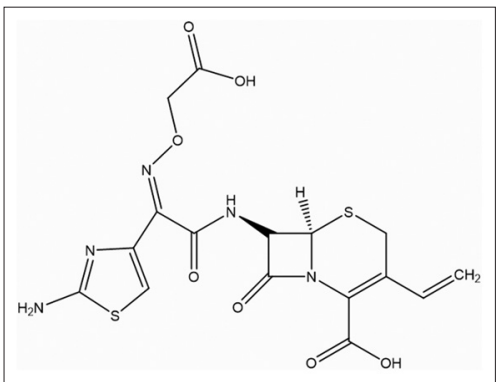

Fig. 1: Structure of cefixime trihydrate

\section{Optimization by RSM}

\section{Method A}

The main, interaction, and quadratic effects of MBTH concentration $\left(\mathrm{X}_{1}\right)$, ferric chloride concentration $\left(\mathrm{X}_{2}\right)$, and the reaction time $\left(\mathrm{X}_{5}\right)$ on the

Table 1: A $2^{5-1}$ experimental run and the response values for Method A

\begin{tabular}{|c|c|c|c|c|c|c|c|}
\hline Std. & Run & $\mathrm{X}_{1}$ & $\mathbf{X}_{2}$ & $\mathbf{X}_{3}$ & $\mathrm{X}_{4}$ & $\mathbf{X}_{5}$ & $\mathbf{Y}$ \\
\hline 7 & 1 & 0.2 & 0.6 & 2.5 & 1.5 & 40 & 0.756 \\
\hline 3 & 2 & 0.2 & 0.6 & 1.5 & 1.5 & 20 & 0.776 \\
\hline 12 & 3 & 0.4 & 0.6 & 1.5 & 2.5 & 20 & 0.761 \\
\hline 10 & 4 & 0.4 & 0.4 & 1.5 & 2.5 & 40 & 0.728 \\
\hline 13 & 5 & 0.2 & 0.4 & 2.5 & 2.5 & 40 & 0.722 \\
\hline 6 & 6 & 0.4 & 0.4 & 2.5 & 1.5 & 40 & 0.731 \\
\hline 15 & 7 & 0.2 & 0.6 & 2.5 & 2.5 & 20 & 0.781 \\
\hline 16 & 8 & 0.4 & 0.6 & 2.5 & 2.5 & 40 & 0.589 \\
\hline 9 & 9 & 0.2 & 0.4 & 1.5 & 2.5 & 20 & 0.696 \\
\hline 4 & 10 & 0.4 & 0.6 & 1.5 & 1.5 & 40 & 0.565 \\
\hline 14 & 11 & 0.4 & 0.4 & 2.5 & 2.5 & 20 & 0.648 \\
\hline 1 & 12 & 0.2 & 0.4 & 1.5 & 1.5 & 40 & 0.729 \\
\hline 8 & 13 & 0.4 & 0.6 & 2.5 & 1.5 & 20 & 0.779 \\
\hline 5 & 14 & 0.2 & 0.4 & 2.5 & 1.5 & 20 & 0.701 \\
\hline 2 & 15 & 0.4 & 0.4 & 1.5 & 1.5 & 20 & 0.652 \\
\hline 11 & 16 & 0.2 & 0.6 & 1.5 & 2.5 & 40 & 0.763 \\
\hline
\end{tabular}

$\mathrm{X}_{1}$-MBTH concentration, $\mathrm{X}_{2}$-ferric chloride concentration, $\mathrm{X}_{3}$-volume of MBTH reagent, $\mathrm{X}_{4}$-volume of ferric chloride, $\mathrm{X}_{5}$-reaction time. MBTH: 3-methyl-2-benzothiazolinone hydrazone hydrochloride

Table 2: A $2^{4-1}$ experimental run and the response values for Method B

\begin{tabular}{lllllll}
\hline Std. & Run & $\mathbf{X}_{\mathbf{1}}$ & $\mathbf{X}_{\mathbf{2}}$ & $\mathbf{X}_{\mathbf{3}}$ & $\mathbf{X}_{\mathbf{4}}$ & $\mathbf{Y}$ \\
\hline 1 & 1 & 0.1 & 0.3 & 15 & 35 & 0.374 \\
7 & 2 & 0.1 & 0.5 & 25 & 35 & 0.345 \\
8 & 3 & 0.3 & 0.5 & 25 & 45 & 0.451 \\
4 & 4 & 0.3 & 0.5 & 15 & 35 & 0.451 \\
5 & 5 & 0.1 & 0.3 & 25 & 45 & 0.363 \\
6 & 6 & 0.3 & 0.3 & 25 & 35 & 0.423 \\
2 & 7 & 0.3 & 0.3 & 15 & 45 & 0.426 \\
3 & 8 & 0.1 & 0.5 & 15 & 45 & 0.358 \\
\hline
\end{tabular}

$\mathrm{X}_{1}-1,10$ phenanthroline concentration, $\mathrm{X}_{2}$-ferric chloride concentration, $\mathrm{X}_{3}$-heating time, $\mathrm{X}_{4}$-heating temperature

Table 3: Central composite design matrix for optimization for Method A

\begin{tabular}{llllll}
\hline Std. & Run & $\mathbf{X}_{\mathbf{1}}$ & $\mathbf{X}_{\mathbf{2}}$ & $\mathbf{X}_{\mathbf{5}}$ & $\mathbf{Y}$ \\
\hline 13 & 1 & 0.3 & 0.5 & 13.18 & 0.742 \\
12 & 2 & 0.3 & 0.66 & 30 & 0.758 \\
1 & 3 & 0.2 & 0.4 & 20 & 0.888 \\
5 & 4 & 0.2 & 0.4 & 40 & 0.763 \\
20 & 5 & 0.3 & 0.5 & 30 & 0.856 \\
18 & 6 & 0.3 & 0.5 & 30 & 0.843 \\
10 & 7 & 0.46 & 0.5 & 30 & 0.762 \\
2 & 8 & 0.4 & 0.4 & 20 & 0.693 \\
3 & 9 & 0.2 & 0.6 & 20 & 0.851 \\
7 & 10 & 0.2 & 0.6 & 40 & 0.621 \\
15 & 11 & 0.3 & 0.5 & 30 & 0.851 \\
11 & 12 & 0.3 & 0.33 & 30 & 0.763 \\
19 & 13 & 0.3 & 0.5 & 30 & 0.831 \\
6 & 14 & 0.4 & 0.4 & 40 & 0.861 \\
17 & 15 & 0.3 & 0.5 & 30 & 0.849 \\
9 & 16 & 0.13 & 0.5 & 30 & 0.822 \\
4 & 17 & 0.4 & 0.6 & 20 & 0.792 \\
16 & 18 & 0.3 & 0.5 & 30 & 0.838 \\
8 & 19 & 0.4 & 0.6 & 40 & 0.889 \\
14 & 20 & 0.3 & 0.5 & 46.81 & 0.828 \\
\hline$X-M B$
\end{tabular}

$\mathrm{X}_{1}$-MBTH concentration, $\mathrm{X}_{2}$-ferric chloride concentration, $\mathrm{X}_{5}$-reaction time. MBTH: 3-methyl-2-benzothiazolinone hydrazone hydrochloride 
absorbance were studied using a two-level three-factor twenty run central composite design with six midpoints, as presented in Table 3. The experimental conditions such as the volume of MBTH and volume of ferric chloride were held constant.

\section{Method B}

The main, interaction, and quadratic effects of 1,10 phenanthroline $\left(X_{1}\right)$, ferric chloride concentration $\left(\mathrm{X}_{2}\right)$, and the heating time $\left(\mathrm{X}_{3}\right)$ on the absorbance were studied using a two-level three-factor 20 run central composite design, as presented in Table 4 . The heating temperature was held constant at $40^{\circ} \mathrm{C}$.

Table 4: Central composite design matrix for optimization for Method B

\begin{tabular}{llllll}
\hline Std. & Run & $\mathbf{X}_{\mathbf{1}}$ & $\mathbf{X}_{\mathbf{2}}$ & $\mathbf{X}_{\mathbf{3}}$ & $\mathbf{Y}$ \\
\hline 13 & 1 & 0.1 & 0.5 & 15 & 0.25 \\
12 & 2 & 0.2 & 0.4 & 20 & 0.334 \\
1 & 3 & 0.3 & 0.5 & 25 & 0.431 \\
5 & 4 & 0.2 & 0.4 & 20 & 0.362 \\
20 & 5 & 0.2 & 0.23 & 20 & 0.234 \\
18 & 6 & 0.1 & 0.5 & 25 & 0.352 \\
10 & 7 & 0.2 & 0.4 & 11.59 & 0.245 \\
2 & 8 & 0.1 & 0.3 & 25 & 0.315 \\
3 & 9 & 0.2 & 0.4 & 20 & 0.336 \\
7 & 10 & 0.3 & 0.5 & 15 & 0.363 \\
15 & 11 & 0.1 & 0.3 & 15 & 0.209 \\
11 & 12 & 0.3 & 0.3 & 25 & 0.342 \\
19 & 13 & 0.2 & 0.56 & 20 & 0.432 \\
6 & 14 & 0.03 & 0.4 & 20 & 0.197 \\
17 & 15 & 0.2 & 0.4 & 28.40 & 0.419 \\
9 & 16 & 0.2 & 0.4 & 20 & 0.312 \\
4 & 17 & 0.2 & 0.4 & 20 & 0.323 \\
16 & 18 & 0.2 & 0.4 & 20 & 0.351 \\
8 & 19 & 0.3 & 0.3 & 15 & 0.285 \\
14 & 20 & 0.36 & 0.4 & 20 & 0.398 \\
\hline
\end{tabular}

$\mathrm{X}_{1}-1,10$ phenanthroline concentration, $\mathrm{X}_{2}$-ferric chloride concentration,

$\mathrm{X}_{3}$-heating time

\section{Linearity}

Method A

Various volumes of the stock solution $(0.06-0.14 \mathrm{ml})$ were pipetted into a $10.0 \mathrm{ml}$ volumetric flask, $2 \mathrm{ml}$ of $0.4 \% \mathrm{w} / \mathrm{v}$ ferric chloride, and $2 \mathrm{ml}$ of $0.2 \% \mathrm{w} / \mathrm{v}$ MBTH were added and allowed to stand for $20 \mathrm{~min}$. The final volume was adjusted to the mark with distilled water. The resultant solution was scanned between 400 and $800 \mathrm{~nm}$ using an appropriate reagent blank. The $\lambda_{\text {max }}$ was at $630 \mathrm{~nm}$, and hence, it was selected for further investigation (Fig. 2).

\section{Method B}

Various volumes of the stock solution $(0.09-0.21 \mathrm{ml})$ were pipetted into a $10.0 \mathrm{ml}$ volumetric flask. To this, $0.5 \mathrm{ml}$ of $0.3 \% \mathrm{w} / \mathrm{v}$ ferric chloride and $1 \mathrm{ml}$ of $0.12 \% \mathrm{w} / \mathrm{v} 1,10$ phenanthrolines were added and heated on a water bath for $15 \mathrm{~min}$ at $40^{\circ} \mathrm{C}$. Further, the temperature was brought down to room temperature and the final volume was brought to the mark with distilled water. The resulting solution was subjected for scanning between 400 and $800 \mathrm{~nm}$ against appropriate reagent blank. The $\lambda$ was at $520 \mathrm{~nm}$, and hence, it was selected for further analysis (Fig. 3).

\section{Precision}

The intraday and interday precision was resolved by analyzing the sample at different days and repeatedly on the same day, respectively, for both methods A and B.

\section{Evaluation of CFT in the pharmaceutical formulation}

Method A

From the stock and sample solutions, $0.1 \mathrm{ml}$ was pipetted into a $10 \mathrm{ml}$ volumetric flasks. To $2 \mathrm{ml}$ of $0.4 \%$, w/v ferric chloride followed by $2 \mathrm{ml}$ of $0.2 \% \mathrm{w} / \mathrm{v}$ MBTH reagent was added and allowed to stand for $20 \mathrm{~min}$. The final volume was adjusted to the mark with distilled water and the absorbances of both the solutions were recorded at $630 \mathrm{~nm}$

\section{Method B}

From the stock and sample solutions, $0.15 \mathrm{ml}$ was pipetted into $10 \mathrm{ml}$ volumetric flasks. To this, $0.5 \mathrm{ml}$ of $0.3 \% \mathrm{w} / \mathrm{v}$ ferric chloride, $1 \mathrm{ml}$ of $0.12 \% \mathrm{w} / \mathrm{v} 1$, and 10 phenanthroline reagent were added and heated

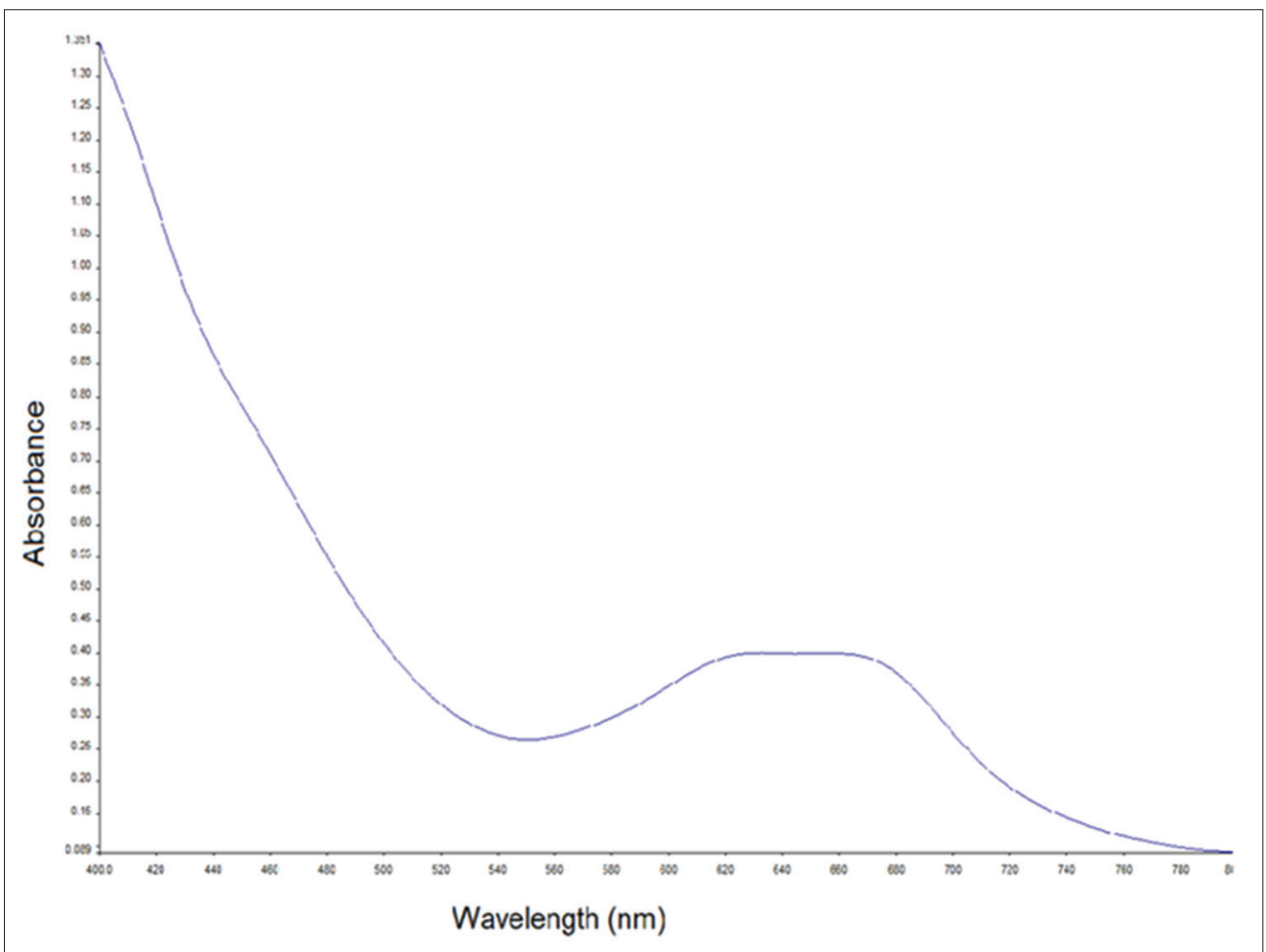

Fig. 2: Ultraviolet-visible spectrum of cefixime trihydrate - 3-methyl-2-benzothiazolinone hydrazone hydrochloride complex (10 $\mu$ g/mL) 


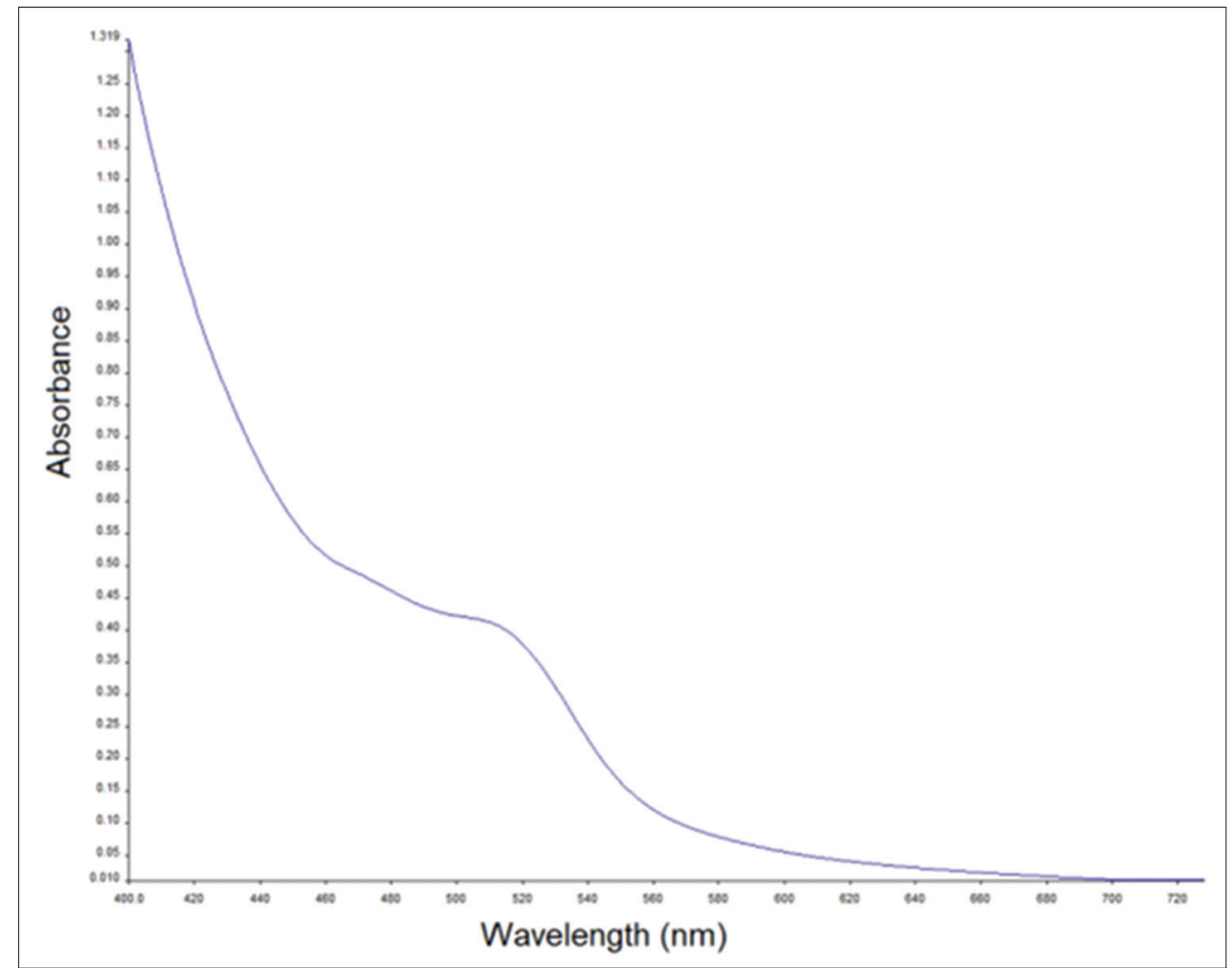

Fig. 3: Ultraviolet-visible spectrum of cefixime trihydrate - phenanthroline complex $(10 \mu \mathrm{g} / \mathrm{mL})$

on a water bath at $40^{\circ} \mathrm{C}$ for $15 \mathrm{~min}$. Further, the temperature of the solution was brought down to room temperature, the final volume was then brought to the mark with distilled water and the absorbance of sample and standard solution was noted at $520 \mathrm{~nm}$.

The amount of CFT in the chosen pharmaceutical formulation was estimated by the formula given below

$\mathrm{CFT}_{(\mathrm{est})}=\frac{\mathrm{A}_{(\mathrm{x})} \mathrm{XW}_{(\mathrm{std})} \mathrm{XW}_{(\mathrm{avg})}}{\mathrm{A}_{(\mathrm{std})} \mathrm{XW}_{(\mathrm{x})}}$

\%labelclaim $=\frac{\mathrm{CFT}_{(\mathrm{est})} \times 100}{\mathrm{CFT}_{\mathrm{LC}}}$

where, $\mathrm{CFT}_{(\text {est) }}=$ amount of CFT per tablet; $\mathrm{A}_{\mathrm{x}}=$ sample absorbance; $\mathrm{A}_{\text {(std) }}=$ standard absorbance; $\mathrm{W}_{\text {(std) }}=$ weight of the standard (mg); $\mathrm{W}_{(\text {avg) }}=$ average weight of a tablet $(\mathrm{mg}) ; \mathrm{W}_{(\mathrm{x})}=$ weight of the sample taken (mg) and CFT ${ }_{(\mathrm{LC})}=$ label claim of CFT per tablet (mg).

\section{Accuracy}

Recovery studies were employed to study the accuracy of the proposed method at three concentration levels $(80 \%, 100 \%$, and $120 \%)$.

\section{Method A}

A known amount of the standard CFT $(0.3 \mathrm{ml})$ was added to different volumes $(0.5 \mathrm{ml}, 0.7 \mathrm{~mL}$, and $0.9 \mathrm{ml})$ of the sample solution and subjected to developed experimental conditions.

\section{Method B}

A known amount of the standard CFT $(0.3 \mathrm{ml})$ was added to different volumes $(0.6 \mathrm{ml}, 0.12 \mathrm{ml}$, and $0.18 \mathrm{ml})$ of the sample solution and subjected to the developed experimental conditions.

The percentage recovery for both methods was calculated by applying the following formula

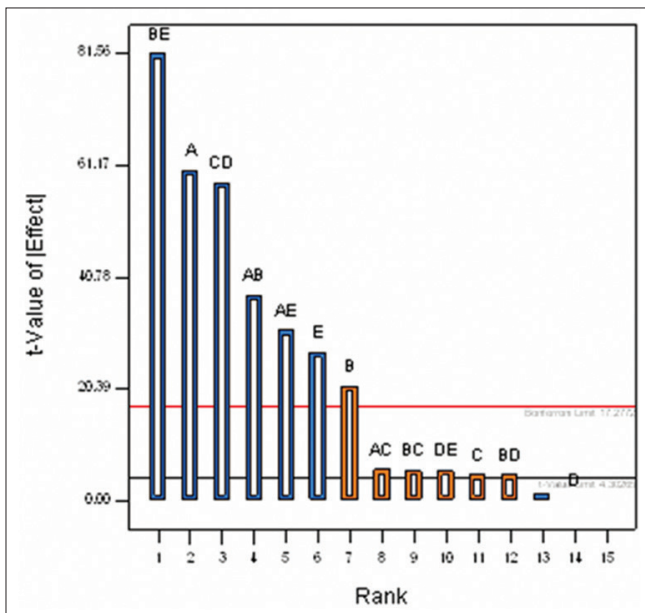

Fig. 4: Pareto Chart showing the effect of critical variables - Method A. A - 3-methyl-2-benzothiazolinone hydrazone

hydrochloride (MBTH) concentration, B - ferric chloride concentration, $\mathrm{C}$ - volume of $\mathrm{MBTH}$ reagent, $\mathrm{D}$ - volume of ferric chloride, $\mathrm{E}$ - reaction time

$\%$ Recovery $=\frac{E}{T+P} \times 100$

Where $\mathrm{E}=$ amount of CFT estimated $(\mathrm{mg}), \mathrm{T}=$ amount of CFT from the sample solution (mg), and P = amount of standard CFT added (mg).

\section{RESULTS AND DISCUSSION}

Two visible spectrophotometric methods were optimized for the quantification of CFT using MBTH (method A) and 1, 10 phenanthroline (method B) as the derivatizing reagents. The experimental design approach was utilized for screening most significant factors and optimization of those significant factors having an influence on the 
response by central composite design (absorbance of CFT - MBTH complex and CFT - phenanthroline complex in methods A and B).

\section{Two levels FFD}

Screening designs allow us to look at a considerable number of components in a minimal number of blends.

\section{Method A}

A two-level five-factor sixteen-run fractional factorial model was adopted to examine the main effect of the independent variables on the chosen response (absorbance). The impact of each factor was interpreted on the response CFT-MBTH complex when the factor changed from the selected minimum level to maximum level. The impacts of all the variables incorporated into the experimental model on the chosen response are shown in Table 1. An impact was treated to be significant $p \leq 0.05$. These factors are considered as influencing factors (IF). A half-normal plot was used to choose the statistically significant effects and a Pareto chart was used for checking the significance of the next largest unselected effect $(\mathrm{p} \leq 0.05)$ for the preferred response. The Pareto chart (Fig. 4) was determined from the multivariate regression analyses, and the impacts over the Bonferroni limit were almost positively huge, and the effects above the t-value are perhaps noteworthy and must be considered on the off chance that they are not effectively chosen. The MBTH concentration $\left(\mathrm{X}_{1}\right)$, ferric chloride concentration $\left(\mathrm{X}_{2}\right)$, and the reaction time $\left(\mathrm{X}_{5}\right)$ have a coordinate relationship with the absorbance, and their effects are statistically critical $(\mathrm{p} \leq 0.05)$. The other variables such as volume of MBTH reagent $\left(\mathrm{X}_{3}\right)$ and volume of ferric chloride $\left(\mathrm{X}_{4}\right)$ directly affects the chosen response, but they are statistically unimportant $(p>0.05)$.

\section{Method B}

A two-level four-factor eight-run fractional factorial model was adopted to examine the main effect of the independent variables on the chosen response (absorbance). The impact of each factor was interpreted on the response CFT - 1, 10 Phenanthroline complex, when the factor changed from a selected minimum level to maximum level. The effects of all the variables incorporated into the experimental model on the chosen response are shown in Table 2. An impact was treated to be significant when $\mathrm{p} \leq 0.05$. These factors are considered as IF. A halfnormal plot was used to choose the statistically significant effects, and a Pareto chart was used for checking the significance of the next largest unselected effect $(\mathrm{p} \leq 0.05)$ for the preferred response. The significant factors were 1,10 phenanthroline concentration $\left(X_{1}\right)$, ferric chloride concentration $\left(\mathrm{X}_{2}\right)$, and the heating time $\left(\mathrm{X}_{3}\right)$. The Pareto charts (Fig. 5) was derived from the multivariate regression analyses, and the impacts over the Bonferroni limit were almost positively huge, and the effects above the t-value are perhaps noteworthy and must be considered on the off chance that they are not effectively chosen. 1,10 phenanthroline concentration $\left(\mathrm{X}_{1}\right)$, ferric chloride concentration $\left(\mathrm{X}_{2}\right)$, and the heating time $\left(\mathrm{X}_{3}\right)$ have coordinate relationship with the absorbance, and their effects are statistically critical $(\mathrm{p} \leq 0.05)$. The other variable heating temperature $\left(\mathrm{X}_{4}\right)$ directly affects the chosen response, but it is statistically unimportant $(\mathrm{p}>0.05)$.

\section{Response surface design - central composite design} Method A

Utilizing multivariate regression analysis, a quadratic model was acquired for the moderate response by the ensuing equation,

Absorbance $=0.75+0.04 \times \mathrm{X}_{1}+0.045 \times \mathrm{X}_{2}+0.047 \times \mathrm{X}_{3}-0.002625 \times \mathrm{X}_{1} \mathrm{X}_{2}+0.001$ $875 \times \mathrm{X}_{1} \mathrm{X}_{3}+0.002875 \times \mathrm{X}_{2} \mathrm{X}_{3}+0.002303 \times \mathrm{X}_{1}^{2}+0.001950 \times \mathrm{X}_{2}^{2}+$ $0.002303 \times \mathrm{X}_{3}^{2}$

Tables 5 and 6 demonstrate the estimation of regression coefficients and their related p-values. The interactions between the selected independent factors with their $\mathrm{p}$ values are presented in Table 5. It can be seen that the MBTH concentration ( $X_{1}$ ), ferric chloride concentration $\left(\mathrm{X}_{2}\right)$, and the reaction time $\left(\mathrm{X}_{5}\right)$ significantly affects the response of the CFT - MBTH complex $(\mathrm{p}<0.05)$.
A steep slope or a curvature in the perturbation plot of a factor shows that the response is sensitive to that factor, as shown in Fig. 6. Response surface plots were examined to study the impacts of the variables on

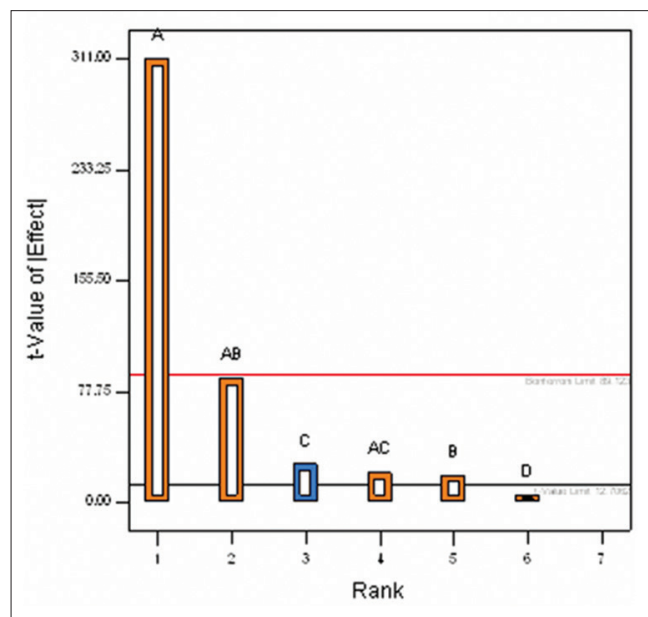

Fig. 5: Pareto chart showing the effect of critical variables -

Method B. A - 1, 10 phenanthroline concentration, B - ferric chloride concentration, $\mathrm{C}$ - heating time, $\mathrm{D}$ - heating temperature

Table 5: Analysis of variance for the selected response surface quadratic model for Method A

\begin{tabular}{|c|c|c|c|c|c|}
\hline Source & DF & $\begin{array}{l}\text { Sum of } \\
\text { squares }\end{array}$ & $\begin{array}{l}\text { Mean } \\
\text { square }\end{array}$ & F value & $p$ value \\
\hline Model & 9 & 0.085 & 0.009396 & 178 & 0.000 \\
\hline MBTH con & 1 & 0.026 & 0.026 & 493.45 & 0.000 \\
\hline FC con & 1 & 0.028 & 0.028 & 521.98 & 0.000 \\
\hline RT & 1 & 0.031 & 0.031 & 580.47 & 0.000 \\
\hline $\begin{array}{l}\text { MBTH con×FC } \\
\text { con }\end{array}$ & 1 & 0.000055 & 0.000055 & 1.04 & 0.3309 \\
\hline MBTH con×RT & 1 & 0.000028 & 0.000028 & 0.53 & 0.4822 \\
\hline $\mathrm{FC} \operatorname{con} \times \mathrm{RT}$ & 1 & 0.000066 & 0.000066 & 1.25 & 0.2892 \\
\hline $\begin{array}{l}\text { MBTH } \\
\text { con } \times \text { MBTH con }\end{array}$ & 1 & 0.000076 & 0.000076 & 1.45 & 0.2565 \\
\hline $\mathrm{FC} \operatorname{con} \times \mathrm{FC}$ con & 1 & 0.000054 & 0.000054 & 1.04 & 0.3323 \\
\hline $\mathrm{RT} \times \mathrm{RT}$ & 1 & 0.000076 & 0.000076 & 1.45 & 0.2565 \\
\hline Residual & 10 & 0.000527 & 0.000052 & & \\
\hline Lack of fit & 5 & 0.000417 & 0.000083 & 3.76 & 0.0861 \\
\hline Pure error & 5 & 0.000110 & 0.000022 & - & - \\
\hline Cor total & 19 & 0.085 & - & - & - \\
\hline
\end{tabular}

MBTH: 3-methyl-2-benzothiazolinone hydrazone hydrochloride, FC: Ferric chloride, RT: Reaction time, Con: Concentration, Cor: Correlation

Table 6: Estimated regression coefficient for the selected response for Method A

\begin{tabular}{lllll}
\hline Factor & $\begin{array}{l}\text { Coefficient } \\
\text { estimate }\end{array}$ & DF & SE & p value \\
\hline Intercept & 0.75 & 1 & 0.002963 & - \\
MBTH con & 0.044 & 1 & 0.001966 & 0.000 \\
FC con & 0.045 & 1 & 0.001966 & 0.000 \\
RT & 0.047 & 1 & 0.001966 & 0.000 \\
MBTH con $\times$ FC con & 0.002625 & 1 & 0.002569 & 0.330 \\
MBTH con $\times$ RT & 0.001875 & 1 & 0.002569 & 0.482 \\
FC con $\times$ RT & 0.002875 & 1 & 0.002569 & 0.289 \\
MBTH con $\times$ MBTH & 0.002303 & 1 & 0.001914 & 0.256 \\
con & & & & \\
FC con $\times$ FC con & 0.001950 & 1 & 0.001914 & 0.332 \\
RT $\times$ RT & 0.002303 & 1 & 0.001914 & 0.256 \\
\hline MBTH $3-m e t h l-2-b e n t$
\end{tabular}

MBTH: 3-methyl-2-benzothiazolinone hydrazone hydrochloride, FC: Ferric chloride, RT: Reaction time, Con: Concentration, DF: Degrees of freedom, SE: Standard error 
the chosen response. The impact of MBTH concentration $\left(\mathrm{X}_{1}\right)$, ferric chloride concentration $\left(\mathrm{X}_{2}\right)$, and the reaction time $\left(\mathrm{X}_{5}\right)$ on the chosen response is demonstrated in Fig. 7. From the response surface plots, it

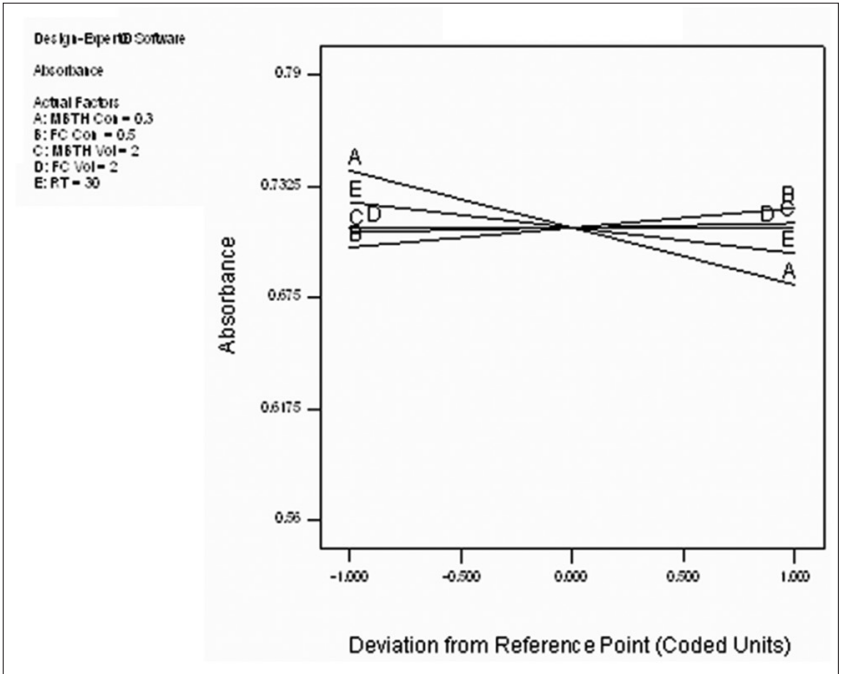

Fig. 6: Perturbation plot showing the effect of critical variables on absorbance - Method A can be identified that $2 \mathrm{ml}$ of $0.201 \% \mathrm{w} / \mathrm{v}$ MBTH concentration, $2 \mathrm{ml}$ of $0.4 \% \mathrm{w} / \mathrm{v}$ ferric chloride concentration with a reaction time of about 20 min gives the maximum response.

\section{Method B}

Using multivariate regression analysis, a quadratic model was obtained for the average response $Y$, given by the following equation,

Absorbance $=0.75+0.04 \times \mathrm{X}_{1}+0.045 \times \mathrm{X}_{2}+0.047 \times \mathrm{X}_{3}-0.002625 \times \mathrm{X}_{1} \mathrm{X}_{2}+0.001$ $875 \times \mathrm{X}_{1} \mathrm{X}_{3}+0.002875 \times \mathrm{X}_{2} \mathrm{X}_{3}+0.002303 \times \mathrm{X}_{1}^{2}+0.001950 \times \mathrm{X}_{2}^{2}+$ $0.002303 \times \mathrm{X}_{3}^{2}$

Tables 7 and 8 demonstrate the estimation of regression coefficients and their related p-values. The interactions between the selected independent factors with their $\mathrm{p}$ values are presented in Table 7. It can be seen that 1,10 phenanthroline concentration $\left(\mathrm{X}_{1}\right)$, ferric chloride concentration $\left(\mathrm{X}_{2}\right)$, and the heating time $\left(\mathrm{X}_{3}\right)$ significantly affects the response of the CFT - 1, 10 phenanthroline complex $(\mathrm{p}<0.05)$.

A steep slope or a curvature in the perturbation plot of a factor shows that the response is sensitive to that factor, as shown in Fig. 8.

Response surface plots were examined to study the impacts of the parameters on the chosen response. Fig. 9 depicts the impacts of 1,10 phenanthroline concentration $\left(\mathrm{X}_{1}\right)$, ferric chloride concentration $\left(\mathrm{X}_{2}\right)$, and the heating time $\left(\mathrm{X}_{3}\right)$ on the chosen response. From the response

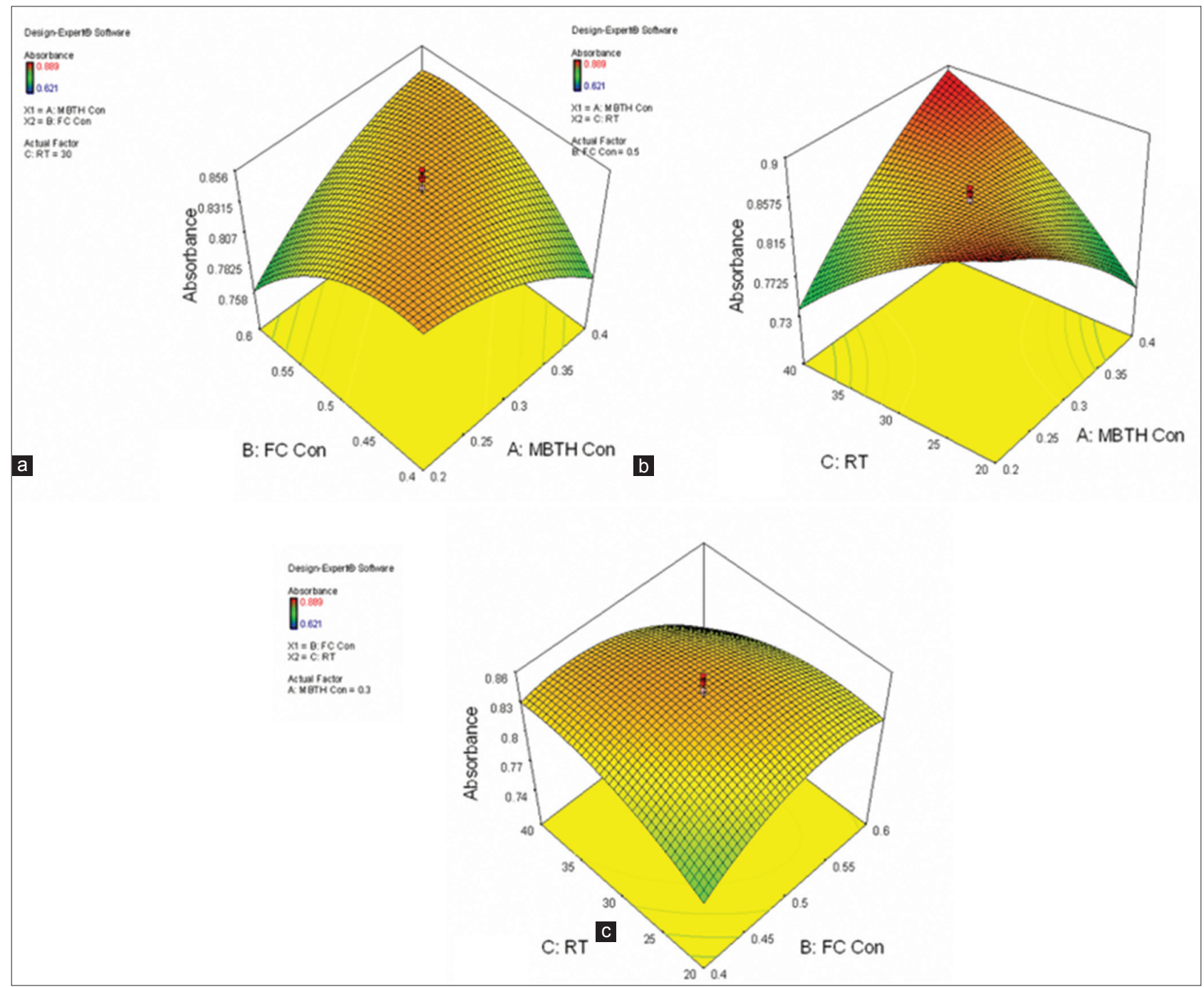

Fig. 7: Response surface plots on selected response - Method A. (a) 3-methyl-2-benzothiazolinone hydrazone hydrochloride (MBTH) con versus ferric chloride (FC) con; (b) MBTH con versus reaction time (RT); (c) FC con versus RT 
surface plots, it can be identified that $0.5 \mathrm{ml}$ of $0.3 \% \mathrm{w} / \mathrm{v}$ ferric chloride concentration, $1 \mathrm{ml}$ of $0.12 \% \mathrm{w} / \mathrm{v} 1$, and 10 phenanthroline concentration, with a heating time of about 15 min gives the maximum response.

\section{Model validation}

The experiential outcome and the expected values achieved by the polynomial model have shown that the expected standards match

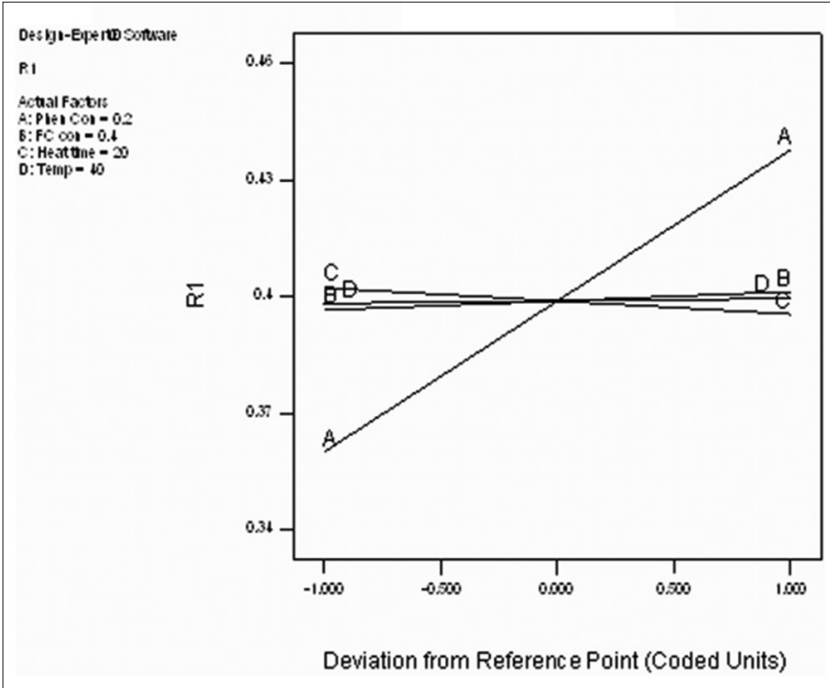

Fig. 8: Perturbation plot showing the effect of critical variables on absorbance - Method B with the chosen response considerably with the R-squared value of 99.38\%, 96.12\% and an adjusted R-squared value of 98.82\%, 92.62\% for methods A and B, respectively.

\section{Linearity}

The calibration graph of the CFT was constructed between concentration and absorbance by the optimized method, as illustrated above. A good linearity was obtained in the selected concentration range of 6-14 $\mu \mathrm{g} / \mathrm{ml}$ and $9-21 \mu \mathrm{g} / \mathrm{ml}$ for methods A and B. The statistical data for the linearity are represented in Table 9.

\section{Precision}

The intraday and interday precision was resolved by analyzing the sample at different days and repeatedly on the same day, respectively. The percentage relative standard deviation (\% RSD) values were within the limits, as illustrated in Table 9, indicating the method was precise.

\section{Assay of CFT in pharmaceutical formulations}

The outcomes obtained for the procured formulations from the market are given in Table 9. The assay values were found to be within the prescribed limits.

\section{Accuracy}

Recovery studies were used to study the accuracy of the proposed method at three concentration levels $(80 \%, 100 \%$, and $120 \%)$. The average percent recoveries are given in Table 9 .

\section{Solution stability}

The stability of the solution was determined for $48 \mathrm{~h}$ stored at room temperature. The solutions were analyzed at $0,20,40$, and $60 \mathrm{~min}, 2,4$,

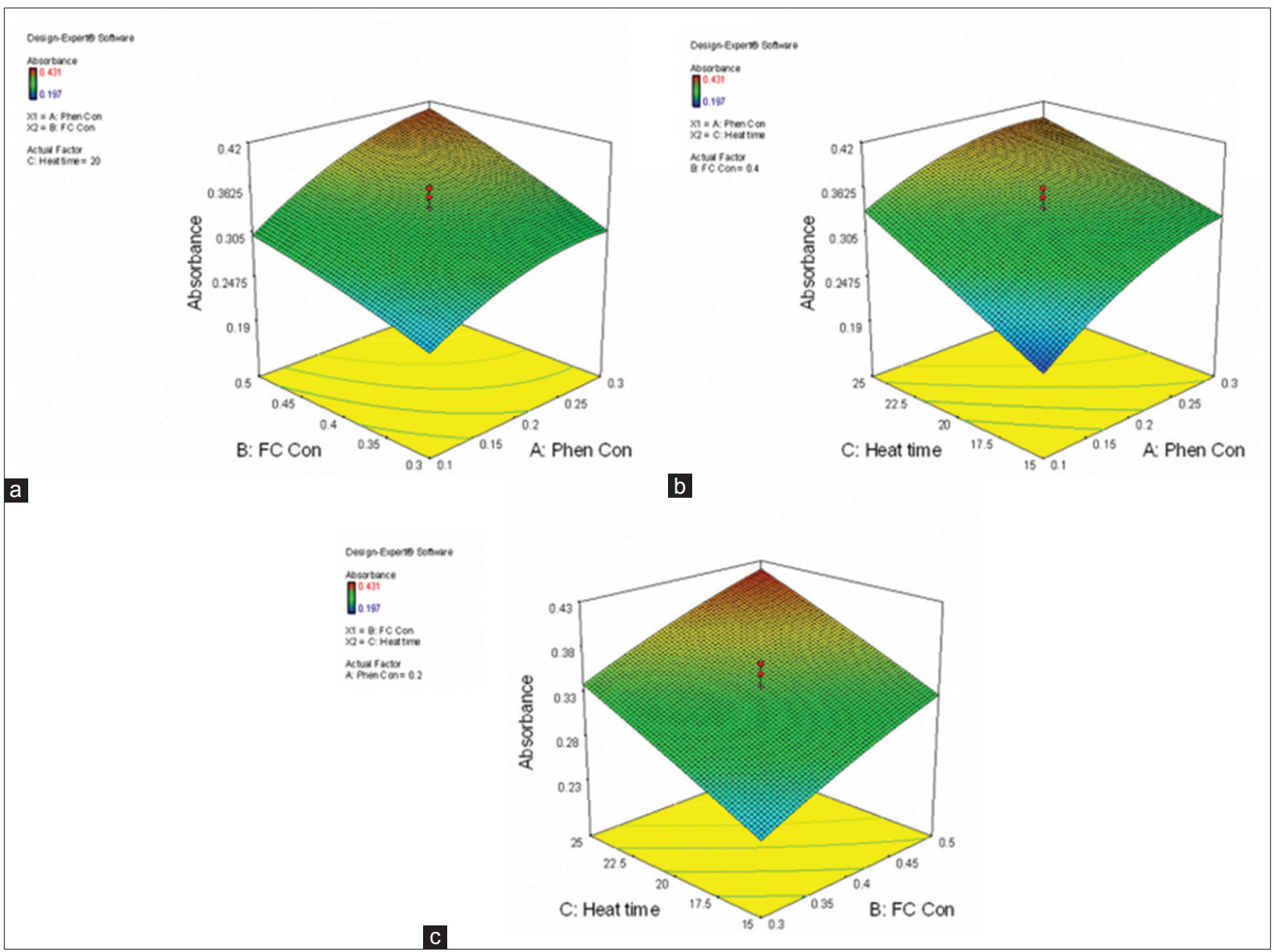

Fig. 9: Response surface plots on response - Method B. (a) Phen con versus ferric chloride (FC) con; (b) 3-methyl-2-benzothiazolinone hydrazone hydrochloride con versus heat time, (c) FC con versus heat time 
Table 7: Analysis of variance for the selected response surface quadratic model for Method B

\begin{tabular}{|c|c|c|c|c|c|}
\hline Source & DF & $\begin{array}{l}\text { Sum of } \\
\text { squares }\end{array}$ & $\begin{array}{l}\text { Mean } \\
\text { square }\end{array}$ & F value & p value \\
\hline Model & 9 & 0.085 & 0.009466 & 27.50 & 0.000 \\
\hline Phen Con & 1 & 0.026 & 0.026 & 74.95 & 0.000 \\
\hline FC Con & 1 & 0.023 & 0.023 & 65.60 & 0.000 \\
\hline Heat time & 1 & 0.030 & 0.030 & 86.21 & 0.000 \\
\hline Phen $\operatorname{con} \times \mathrm{FC}$ con & 1 & 0.000760 & 0.000760 & 2.21 & 0.168 \\
\hline Phen con $\times$ heat time & 1 & 0.001104 & 0.001104 & 3.21 & 0.103 \\
\hline FC con $\times$ heat time & 1 & 0.000002 & 0.000002 & 0.005 & 0.940 \\
\hline Phen con $\times$ Phen Con & 1 & 0.005156 & 0.005156 & 14.98 & 0.003 \\
\hline FC Con $\times$ FC Con & 1 & 0.000304 & 0.000304 & 0.88 & 0.369 \\
\hline Heat time $\times$ heat time & 1 & 0.000028 & 0.000028 & 0.084 & 0.778 \\
\hline Residual & 10 & 0.003442 & 0.003442 & - & - \\
\hline Lack of fit & 5 & 0.002433 & 0.000486 & 2.41 & 0.178 \\
\hline Pure error & 5 & 0.001009 & 0.000201 & - & - \\
\hline Cor total & 19 & 0.089 & - & - & - \\
\hline
\end{tabular}

Phen-1, 10 phenanthroline, FC: Ferric chloride, Con: Concentration, Cor: Correlation

Table 8: Estimated regression coefficient for the selected response for Method B

\begin{tabular}{lllll}
\hline Factor & $\begin{array}{l}\text { Coefficient } \\
\text { estimate }\end{array}$ & DF & SE & p value \\
\hline Intercept & 0.34 & 1 & 0.007567 & \\
Phen con & 0.043 & 1 & 0.005021 & 0.000 \\
FC con & 0.041 & 1 & 0.005021 & 0.000 \\
Heat time & 0.047 & 1 & 0.005021 & 0.000 \\
Phen con $\times$ FC con & 0.00975 & 1 & 0.006560 & 0.168 \\
Phen con $\times$ heat time & -0.012 & 1 & 0.006560 & 0.103 \\
FC con $\times$ heat time & -0.0005 & 1 & 0.006560 & 0.940 \\
Phen con $\times$ phen con & -0.019 & 1 & 0.004887 & 0.003 \\
FC con $\times$ FC con & -0.0045 & 1 & 0.004887 & 0.369 \\
Heat time $\times$ heat time & -0.0014 & 1 & 0.004887 & 0.778 \\
\hline
\end{tabular}

Phen-1, 10 phenanthroline, FC: Ferric chloride, Con: Concentration, DF: Degrees of freedom, SE: Standard error

Table 9: Statistical data for validation parameters by the proposed methods

\begin{tabular}{lll}
\hline Parameter & \multicolumn{2}{l}{ Results } \\
\cline { 2 - 3 } & Method A & Method B \\
\hline Color & Green & Reddish orange \\
Regression equation & Y=0.0623x+0.1012 & Y=0.0247x+0.0805 \\
$\lambda_{\max }(\mathrm{nm})$ & 630 & 520 \\
Beer's law $(\mu \mathrm{g} / \mathrm{ml})$ & $6-14$ & $9-21$ \\
Slope & 0.0623 & 0.0247 \\
Intercept & 0.1012 & 0.0805 \\
Correlation & 0.9983 & 0.9986 \\
coefficient & & \\
Precision & & \\
$\quad$ Intraday & 0.9214 & 0.1919 \\
$\quad$ Interday & 1.025 & 0.2136 \\
Assay & & \\
Amount $(\mathrm{mg})$ & 197.25 & 198.76 \\
$\quad$ Percentage & 98.62 & 99.38 \\
\% recovery & 100.06 & 99.26 \\
\hline
\end{tabular}

Nm: Nanometer, mg: Milligram

$6,8,10,24$, and $48 \mathrm{~h}$, and the absorbance was noted. The color intensity was found to be stable for $8 \mathrm{~h}$ and $6 \mathrm{~h}$ for method A and B, respectively.

Reaction mechanism

The proposed strategy for method A depends on the oxidative coupling reaction between $\mathrm{CFT}$ and $\mathrm{MBTH}$ in the presence of ferric chloride in acidic condition to give a green colored chromogen exhibiting maximum absorbance at $630 \mathrm{~nm}$ as proposed by Shankar et al. [11]. Method B is based on the oxidation followed by complexation between CFT and 1, 10 phenanthroline in the presence of ferric chloride in acidic condition to give a red colored chromogen with maximum absorbance at $520 \mathrm{~nm}$ as proposed by Shankar et al. [11].

\section{CONCLUSION}

A simple two-level FFD was employed to design the experimental method to evaluate the most affecting factors on the response for methods A and B. Pareto chart and one-way analysis of variance showed that the MBTH concentration, ferric chloride concentration and reaction time were statistically important factors $(\mathrm{p}<0.05)$ influencing the development of CFT - MBTH complex (absorbance) for method A. The main, interaction and quadratic effects of the chosen factors on the response are assessed by central composite design. The response surface plots and contour plots were used to find the optimum values of the selected factors. The experimental values obtained matched well with the predicted values of the response with an R-squared of $99.38 \%$ and an R-squared (adjusted) of $98.82 \%$ for the selected response. Further, the adequate precision value of 52.92 indicates an adequate signal of the proposed method. The method was validated as per the international conference on harmonization Q2 (R1) guidelines employing the optimized conditions for the individual variables. A good linearity was obtained in the concentration range of 6-14 and 9-21 $\mu \mathrm{g} /$ $\mathrm{ml}$ for methods A and B. The percentage RSD for precision was $<2 \%$ and the method was accurate. It can be summarized that the concept of analytical quality by design can be adequately utilized to screen and optimize the experimental conditions for the spectrophotometric determination of CFT in pharmaceutical raw material and pharmaceutical formulations with minimal experimental runs.

\section{ACKNOWLEDGMENT}

The authors are thankful to the Chancellor, SRM Institute of Science and Technology, and the management of SRM College of Pharmacy, SRM Institute of Science and Technology, Kattankulathur, for allowing to carry out the research work in the university facility. We also thank Orchid Pharmaceuticals, Chennai, for providing the gift sample of CFT.

\section{AUTHORS' CONTRIBUTIONS}

All the authors have equally contributed to designing the analysis, collecting data, performing the analysis, and writing the research work in the instructed format to frame the final manuscript in a successful manner.

\section{CONFLICTS OF INTEREST}

The authors report that they have no conflicts of interest in the study.

\section{REFERENCES}

1. Tripathi KD. Essentials of Medical Pharmacology. $5^{\text {th }}$ ed. New Delhi: Jaypee Brothers Medical Publishers; 2013.

2. Pundarikakshudu K, Shah PB. Spectrophotometric, difference spectroscopic, and RP-HPLC methods for the determination of cefixime in pharmaceutical formulations. J AOAC Int 2006;89:987-94.

3. Saleh GA, Askal HF, Darwish IA, EL-Shorbagi AA. Spectrophotometric analytical study for the charge transfer complexation of certain cephalosporin with chloranilic acid. Anal Sci 2003;19:281-7.

4. Pareek V, Tambe SR, Bhalerao SB. Role of different hydrotropic agents in spectrophotomteric and chromatographic estimation of cefixime. Int J Pharm Bio Sci 2010;1:1-10.

5. Virupaxappa BS, Shivaprasad KH, Latha MS. A simple method for the spectrophotometric determination of cefixime in pharmaceuticals. Asian J Res Chem 2011;4:1275-7.

6. Uri JV, Jain TC. Colorimetric detection and spectrophotometric determination of the aminothiazolyl-alkoxyimino p-lactams. J Antibiot 1986;39:669-75

7. El Walily AF, Gazy AA, Belal SF, Khamis EF. Use of cerium (IV) in the spectrophotometric and spectrofluorimetric determinations of 
penicillins and cephalosporins in their pharmaceutical preparations. Spectrosc Lett 2000;33:931-48

8. Agbaba D, Eric S, Karlijikovic-Rajic K, Valdimirov S, Zivanov-Stakic D. Spectrophotometric determination of certain cephalosporin's using ferrihydroxamate method. Spectrosc Lett 1997;30:309-19.

9. Patil VP, Gaikwad AD, Kulkarni VS, Devdhe SJ, Kale SH. Spectrophotometric determination of cefixime in bulk drug using ninhydrin-a model approach. Inventi Rapid Pharm Anal Qual Assur 2012;2:269

10. Ali Ahmed MS, ElbashirAA, Aboul-Enein YH. New spectrophotometric method for determination of cephalosporins in pharmaceutical formulations. Arabian J Chem 2015;8:233-9.

11. Shankar DG, Sushma K, Lakshmi RV, Rao YS, Reddy MN, Murthy TK. Spectrophotometric determination of cefixime trihydrate. Asian J Chem 2001;13:1649-51.

12. Khan MN, Qayum A, Ur Rehman U, Gulab H, Idrees M. Spectrophotometric method for quantitative determination of cefixime in bulk and pharmaceutical preparations using ferroin complex. J Appl Spectrosc 2015;82:705-11.

13. Jain R, Gupta VK, Jadon N, Radhapyari K. Voltammetric determination of cefixime in pharmaceutical sand biological fluids. Anal Biochem 2010;407:79-88.

14. Kandikonda S, Akula G, Pandey VP, Kudaravalli S, Bhupathi S, Reddy SB. Validation of RP-HPLC method for the estimation of cefixime in cefixime oral suspension. Int J Pharm Technol 2010;2:385-95.

15. Raj KA, Yada D, Prabhu C, Manikantan S. Determination of cefixime trihydrate and cefuroxime axetil in bulk drug and pharmaceutical dosage form by HPLC. Int J ChemTech Res 2010;2:334-6.

16. Nanda RK, Gaikwad J, Prakash A. Estimation of cefixime and ordinazole in its pharmaceutical dosage form by spectrophotometric method. J Pharm Res 2009;2:1264-6.

17. Kumar R, Singh P, Singh H. Development of colorimetric method for the analysis of pharmaceutical formulation containing both ofloxacin and cefixime. Int J Pharm Pharm Sci 2011;3:178-9.

18. Sharma R, Pathodiya G, Mishra GP, Sharma M. Simultaneous estimation and validation of cefixime trihydrate and ordinazole in bulk and tablets using hydrotropic solubilizing agents. J Pharm Res 2010;3:2953-5.
19. Rathinavel G, Mukherjee PB, Valarmathy J, Samueljoshua L, Ganesh M, Sivakumar T, et al. A validated RP-HPLC method for simultaneous estimation of cefixime and cloxacillin in tablets. E-J Chem 2005;5:648-51.

20. Khandagle KS, Gandhi SV, Deshpande PB, Gaikwad NV. Simple and sensitive RP-HPLC method for simultaneous estimation of cefixime and ofloxacin in combined tablet dosage form. Int J Pharm Pharm Sci 2011;3:46-8

21. Dhoka MV, Gawande VT, Joshi PP. Simultaneous estimation of cefixime trihydrate and erdosteine in pharmaceutical dosage form by using RP-HPLC. Int J ChemTech Res 2010;2:79-87.

22. Dhola VM, Gawande TV, Joshi PP. Validated HPTLC method for simultaneous quantification of cefixime trihydrate and erdosteine in bulk and combined dosage form. Eurasian J Anal Chem 2013;8:99-106.

23. Eric-Jovanovic S, Agbaba D, Zivanov-Stakic D, Vladimirov S. HPTLC determination of ceftriaxone, cefixime and cefotaxime in dosage forms. J Pharm Biomed Anal 1998;18:893-8.

24. Ravichandran V, Sumithra M. Application of quality by design (CCD Technique) for simultaneous estimation of cefixime and ofloxacin by HPTLC method. Int J Pharm Pharm Sci 2016;8:200-8.

25. Lewis GA, Mathieu D, Phan-Tan-Luu R. Pharmaceutical Experimental Design. New York: MARCEL Dekee Inc.; 1999.

26. Stat-Ease Inc. Design-Expert ${ }^{\circledR}$ Version: 10.0.1.0 64-bit; User guide: Data Analysis and Quality Tools. Minneapolis: Stat-Ease Inc.; 2016.

27. Ferreira SL, Bruns RE, Ferreira HS, Matos GD, David JM, Brandão GC, et al. Box-behnken design: An alternative for the optimization of analytical methods. Anal Chim Acta 2007;597:179-86.

28. Benzerra MA, Santelli RE, Oliveria EP, Villar LS, Escaleira LA. Response surface methodolgy (RSM) as a tool for optimization in analytical chemistry. Talanta 2008;76:965-77.

29. Awotwe-Otoo D, Agarabi C, Faustino PJ, Habib MJ, Lee S, Khan MA, et al. Application of quality by design elements for the development and optimization of an analytical method for protamine sulfate. J Pharm Biomed Anal 2012;62:61-7.

30. ICH. Validation of Analytical Procedures: Text and Methodology Q2 (R1): International Conference on Harmonization. Geneva: IFPMA; 2005 . 